\title{
Development, implementation and real-life use assessment of HIBOOT: a smartphone application for safety, self- assessment and medication adherence for patients with inflammatory arthritis. A user-centred step-by-step approach.
}

Catherine BEAUVAIS ( $\nabla$ catherine.beauvais@aphp.fr)

Hopital Saint-Antoine https://orcid.org/0000-0002-9872-4298

Thao Pham

Aix-Marseille Universite de Provence: Aix-Marseille Universite

Guillaume Montagu

Unknowns, stratgy and innovation

Sophie Gleizes

Unknowns, Strategy and innovation

Francesco Madrisotti

CNRS Laboratoire CERMES3

Alexandre Lafourcade

Institut Pierre Louis d'Epidemiologie et de Sante Publique

Céline Vidal

Clinique Beausoleil, Montpellier

Guillaume Dervin

Clinque Juge Marseille

Pauline Baudard

Centre Hospitalier Universitaire Caen de l'Université de Montréal Centre de Recherche: Centre Hospitalier de l'Universite de Montreal Centre de Recherche

\section{Sandra Desouches}

Hôpital Saint-Antoine, Sorbonne Universitétoine

Florence Tubach

Institut Pierre Louis d'Epidemiologie et de Sante Publique

Julian Le Calvez

Unknowns, Stratégie et innovation

Marie de Quatrebarbes

Unknowns, Stratégie et Innovation

Delphine Lafarge

AFS, association France spondyloarthrite

Laurent Grange

AFLAR Associationfrancaise antirhumatismale

Françoise Alliot-Launois

AFLAR Association francaise de lutte anti rhumatismale utte Antiacridienne

Henri Jeantet

Unknowns, Conseil et innovation

Marie Antignac 
Hopital Saint-Antoine

Sonia Tropé

ANDAR association nationale de defense contre l'arthrite rhumatoide

Ludovic Besset

Unknowns, Stratégie et Innovation

Jérémie Sellam

Hopital Saint-Antoine

\section{Research article}

Keywords: Rheumatoid arthritis, Spondyloarthritis, DMARDs, mhealth, mobile applications, ehealth, safety, adherence, qualitative research, patient education

Posted Date: March 5th, 2021

DOI: https://doi.org/10.21203/rs.3.rs-266018/v1

License: @ (i) This work is licensed under a Creative Commons Attribution 4.0 International License. Read Full License 


\section{Abstract}

Background Mobile health applications (apps) are increasing in interest for enhancing patient self-management in rheumatology. However, few have been developed with the involvement of patients and health professionals and actually used by patients. Objective To develop and implement a mobile app for safety, self-assessment and medication adherence for patients with inflammatory arthritis treated with disease modifying anti-rheumatic drugs (DMARDs) and assess its reallife use. Methods A mixed qualitative-quantitative study including 42 and 344 patients, respectively, identified patients' treatment practices and their use of health apps in general and their needs in terms of content and potential use. A multidisciplinary team including 7 rheumatologists, 3 patient association representatives and 4 members of a digital company developed the first version of the app with face-to-face meetings and patient feedback during the process. After the launch of the app, users' feedback assessment included 7 patients and 3 rheumatologists. The number of app installations, current users, users' requests and functionalities used were collected. Results Preliminary studies indicated numerous safety issues and needs for counselling, leading to the 6 functionalities of the app HIBOOT (OWL in English): a safety checklist before treatment administration, aid in daily life situations related to self-management and safety, treatment reminders, global well-being self-assessment, periodic counselling messages, and a diary to note comments and appointments. The app is free, with no personal data collection. The presentation is a friendly companion that interacts with the user. The content was based on the French recommendations for DMARD management, drug leaflets and public national health websites. HIBOOT was installed 20,500 times from 2017 to 2020, with 4300 regular current users and still increasing usage curves. The checklist, diary and queries on daily life situations were the most used functionalities. Overall, 18,000 requests were identified for information on safety or other patient matters over a 8-month period in 2020 . Scores were 4.4/5 stars at Android and iOS stores. Conclusion HIBOOT is a free app for patients with inflammatory arthritis that was developed with a preliminary qualitative-quantitative study including patients during the process and has scientifically validated content. The number of current users is substantial. Future evaluation of the HIBOOT benefit is needed.

\section{Introduction}

Mobile health applications (mhealth apps) have undergone significant development in recent years and are of increasing interest and usefulness to help patients manage their chronic inflammatory arthritis (IA), that is, rheumatoid arthritis (RA) and spondyloarthritis (SpA) including psoriatic arthritis [1-3]. Most mhealth apps for IA described in the English literature have addressed symptom tracking, including disease activity, pain and fatigue [4-7]. Other outcomes pursued included physical activity [8.9]. A systematic review of mhealth apps in Germany [10] revealed 8 apps for IA, most containing treatment reminders $(5 / 8)$ and exchange functionalities (2/8).

Despite the growing number of apps for patients, some critical issues remain. First, most mhealth apps were designed without including patients in their development [4.10]; patients' involvement in the assessment of apps was often limited to users' opinions at stores [10]. Thus, the recording of patient outcomes or adherence, although useful to improve disease management, may be based mainly on health professional perspectives and less on patient perspectives, whose other needs may have been missed.

In addition, healthcare providers have infrequently contributed to the development of mhealth apps [4.5]. The European League Against Rheumatism (EULAR) recently issued "points to consider," emphasizing that participation of patients and health professionals was essential in the content, development and evaluation of mhealth apps [11].

Few apps for patients have targeted education [5.10]. Patient education is advocated to develop self-care for better autonomy in daily life and for participating in decisions concerning their own health and treatment [12]. Dematerialized education is promoted [12], and apps may have appropriate tools for self-management such as managing medications, problem-solving or coordinating care [3]. Moreover, some educational apps have good quality [8.10]. 
An additional challenge in mhealth apps concerns real-life use because very few apps described in the literature are still available at stores after their launch [4], which suggests potential inadequacy with users' interests in their design or content. The number of current installations and app users is rarely reported, although usage represents a basic assessment of their impact [8]. On the whole, apps for patients with rheumatic and musculoskeletal diseases were found to be heterogenous [10] or with rather low to moderate quality [4], and improvements were still needed.

Among the issues of IA management, medication safety could be interesting to implement in an app and has not been addressed. Highly effective disease-modifying anti-rheumatic drugs (DMARDs) are available to control disease activity and to limit complications and disability in IA [13-17]. The growing number of available DMARDs (> 15 in France) with a wide variety of targets and modes of administration, including recently introduced Janus kinase (JAK) inhibitors, represents a challenge for patients to manage their treatment in everyday life, particularly with regard to preventing infection and other adverse effects [18-19]. Patient education aims to reduce these complications by enhancing patients' safety skills consisting of appropriate behaviors in situations at risk: patients can stop DMARDs in case of fever or infection, planned surgery or pregnancy and increase vaccinations [20-22]. Providing patients with a safety app could be beneficial for maintaining patients' skills over time because patient education has been found effective in the short term only [23].

In this context, we developed an mhealth app called HIBOOTfor patients with IA treated with DMARDs, with safety as the main concern. From the outset, the development was designed to 1) involve patients and health professionals at every stage, 2) be based on preliminary studies to explore patients' needs and preferences and understand the overall aspects of their daily lives that could affect the app's construction, 3) use a step-by-step approach by adjusting the app in line with users' feedback, and 4) evaluate the number of app installations and regular users in real life and the type of use as preliminary markers of impact.

\section{Methods}

\section{Design of the HIBOOT app development}

The development of the app was a step-by-step design (supplementary material 1 ) under the umbrella of the French Society of Rheumatology and managed by a steering committee of 3 rheumatologists (JS, TP, CB), a member of a patient association (ST), a methodologist (FT) and members of a digital company including 3 anthropology researchers involved in qualitative studies (LB, HJ, GM).

Step 1. Mixed-method qualitative-quantitative study

A first qualitative study (Q1) was conducted to investigate patients' practices with DMARDs. The patients were enrolled on a voluntary basis from public hospitals and private offices in 2 locations in France. Patients were outpatients living in urban or semirural areas. A standardized semi-structured interview schedule was developed (supplementary material 2) based on the committee members' own experience and explored 3 main areas: 1) organization of daily life with the disease, 2) practices with pharmacological and non-pharmacological treatments and complementary medicine, and 3 ) the patient, the illness, the patient's social and professional relationships, the impact of IA on daily life, treatment practices, and the relation between adherence and safety. Eligibility criteria were a diagnosis of IA according to the rheumatologist's opinion (RA, SpA) [24-26] and methotrexate and/or bDMARD treatment. To obtain an optimal sample in terms of diversity, the patients were enrolled in predetermined profiles by age, sex, socio-professional status, type of IA and DMARDs and number of previous DMARDs. Medication adherence assessment was not an eligibility criterion, nor was previous use of an mhealth app. Patients were excluded if they did not speak fluent French or had cognitive impairment. The interviews were conducted by 2 anthropologists (GM, FM) with an ethnographic approach based on grounded theory. The interviews were performed in the patient's usual environment (i.e., preferentially in their home). Patient enrolment was stopped when saturation was reached. 
The qualitative study data analysis and the consolidated criteria for reporting qualitative research (COREQ) [27] criteria are presented in supplementary material 3. After qualitative analysis, implications for the app development were deduced and discussed during meetings of the steering committee.

The quantitative survey explored the participants' smartphone use, mhealth app use, non-exhaustive safety issues in daily life related to DMARDs (fever, vaccines etc.), potential content or use of an mhealth app for their IA and motivation for an mhealth app. The inclusion criteria were a diagnosis of IA and treatment with DMARDs. The survey schedule followed from the qualitative study and from the steering committee's input considering the objectives of the app development. The survey was posted on patient association websites and Facebook accounts or proposed anonymously by the investigating rheumatologists, who provided the Internet link to patients in their rheumatology departments. To check the inclusion criteria, patients were invited to state the name of their DMARDs. At analysis, the questionnaires with no available DMARD names were deleted. The quantitative descriptive analysis was performed with R Core Team (2017) (R: A language and environment for statistical computing. R Foundation for Statistical Computing, Vienna, Austria).

Associations between participants' willingness to use an mhealth app (grouped in 2 classes "totally and rather agree" vs "rather not and not at all agree") and participant characteristics were calculated by using parametric or nonparametric tests according to statistical distribution.

Step 2. A multidisciplinary team including the steering committee developed the first version of the app.

The team included 7 rheumatologists, 3 patient association representatives and 4 members of the digital company working in face-to-face meetings. The content was based on the results of step 1. In addition, qualitative interviews were conducted with app IA users throughout the development process, taking into account the look, features and navigation of the app; potential use by patients with hand deformity; and the proper understanding of the information. For safety, situations at risk or requiring patient information were identified and implemented in the app by keywords commonly used by the public. For each situation, 3 information materials were considered: material from the summary of product characteristics, material from institutional recommendations (national health service and other institutional organizations) and guidelines of the French Society of Rheumatology (www.cri-net.com, 02.16.2021) [28-32]. A "patient phrasing" was built by consensus, collectively reviewed by the team to be understandable by patients and the public.

Step 3 consisted of launching the first version of the app by use of a multimodal strategy including communication toward patients, rheumatologists and health professionals.

In step 4, users' feedback was collected on the app use and functionalities by comments at Android and iOS stores and by in-depth interviews of 7 patients with different profiles (current users or non-users, satisfied or not) and 3 rheumatologists, who did or did not recommend the app to their patients.

Step 5 was added 2 years after the app's launch to better understand patient needs and also following the availability in France of new DMARDs including JAK inhibitors whose oral administration could require an update of the app. This step consisted of a second qualitative study (Q2) enrolling RA patients who received all types of DMARDs. The methodology was the same as in step 1 (GM, SG). The schedule was built after a literature review of new issues related to JAK inhibitors [33-34]. The addressed domains were history of the patient care pathway, the patient-doctor relationship, the treatment decision-making process, and medication daily management (supplementary material 4).

Step 6 aimed to improve the app navigation and delivered the current version with the inclusion of the new DMARDs and additional functionalities.

\section{App assessment}

The app was assessed by collecting the number of app installations since the launch; the number of regular users, defined as individuals whose app was in use at least once a month; the number and type of functionalities used from June to 
November 2020; and the type of requests on safety or everyday situations sought via the app from March to November 2020. Scores at stores were collected in January 2021.

\section{Results}

\section{Qualitative studies}

Qualitative studies were conducted in May to June 2016 (Q1) and March 2019 to February 2020 (Q2) and recruited 42 patients (21 patients in Q1 and 21 patients in Q2) (Table 1). The interviews lasted 60 min on average (range 45-120 min). The results are presented together because they show some common findings.

Table 1. Patient demographics and clinical features in the qualitative studies $(n=42)$

\begin{tabular}{|c|c|c|}
\hline Sex & $\begin{array}{l}\text { Male } \\
\text { Female }\end{array}$ & $\begin{array}{c}9 \\
33 \\
\end{array}$ \\
\hline Age (median, range) & & $\begin{array}{c}51(17- \\
82)\end{array}$ \\
\hline Disease type & $\begin{array}{l}\text { RA (mean age, } 51 \text { ) } \\
\text { SpA (mean age, } 42 \text { ) } \\
\text { PsA (mean age, 63) }\end{array}$ & $\begin{array}{c}33 \\
7 \\
2 \\
\end{array}$ \\
\hline Disease duration & $>10$ & 22 \\
\hline & $\begin{array}{l}4-10 \\
2-4 \\
<2\end{array}$ & $\begin{array}{l}7 \\
9 \\
4\end{array}$ \\
\hline Treatment & $\begin{array}{l}\text { cDMARD* monotherapy } \\
\text { bDMARD** monotherapy } \\
\text { tsDMARD monotherapy } \\
\text { cDMARD+bDMARD combotherapy } \\
\text { cDMARD+tsDMARD combotherapy } \\
\text { Including } 1^{\text {st }} \text { or } 2^{\text {nd }} \text { line tsDMARD*** }\end{array}$ & $\begin{array}{l}11 \\
10 \\
9 \\
9 \\
3 \\
4\end{array}$ \\
\hline Socio-professional & Farmer & 1 \\
\hline 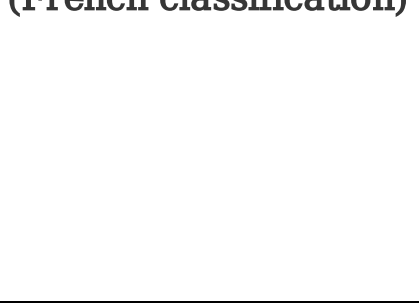 & $\begin{array}{l}\text { Craftsperson, merchant and company head } \\
\text { Senior managers, intermediate managers and intellectual } \\
\text { professions } \\
\text { Intermediate professions } \\
\text { Employees } \\
\text { Manual worker } \\
\text { Retired } \\
\text { Others without professional activities }\end{array}$ & $\begin{array}{l}1 \\
11 \\
5 \\
10 \\
1 \\
7 \\
6\end{array}$ \\
\hline
\end{tabular}

*Conventional DMARD. ** biologic DMARD. *** targeted synthetic DMARD (JAK inhibitors)

RA, rheumatoid arthritis; SpA, spondyloarthritis; PsA, psoriatic arthritis

The thematic analysis revealed 3 themes that would affect the construction and content of the app: living with IA as a career (Fig. 1), acquisition of skills and lay knowledge (Table 2) and patient treatment appropriation practices. Sub-themes were identified and used to build the app, each sub-theme corresponding to one or more of the app's functionalities (Table 3). 
Table 2

Patients' skills and lay knowledge

\begin{tabular}{|c|c|c|c|}
\hline Skills & $\begin{array}{l}\text { Sub- } \\
\text { themes }\end{array}$ & Description & Quotes \\
\hline Coordination & $2 a$ & $\begin{array}{l}\text { Navigate in the } \\
\text { healthcare system, } \\
\text { know which healthcare } \\
\text { professional to consult, } \\
\text { when and how often, } \\
\text { know what to expect } \\
\text { and to demand from } \\
\text { each of them. }\end{array}$ & $\begin{array}{l}\text { "Yeah, it takes a little time to even make an appointment with } \\
\text { a doctor. And then what was really complicated was making } \\
\text { an appointment at the hospital. I had called, I was in the } \\
\text { middle of a crisis [...] and you can't get into the system [...] } \\
\text { and I understood what I had to do, I can write, I can speak, I } \\
\text { can be quite convincing and I think that someone less used } \\
\text { to it than I am must feel really alone." Mr. D, Patient, RA, }\end{array}$ \\
\hline Information & $2 b$ & $\begin{array}{l}\text { Deal with information, } \\
\text { know where to look for } \\
\text { information, how to } \\
\text { identify the most } \\
\text { relevant sources, how to } \\
\text { filter and compute them. }\end{array}$ & $\begin{array}{l}\text { "We did blood typing because spondylitis is a lot of HLA } \\
\text { B27... I'm not HLA B27 but it's the pelvic X-rays that showed } \\
\text { sacroiliac fusion which is a hallmark of the disease, with } \\
\text { inflammation syndrome always high and very high ESR... it's } \\
\text { a marker for the disease plus very high C-reactive protein, it's } \\
\text { the two markers that make it possible for it to be spondylitis." } \\
\text { Mr. S., Patient, SpA }\end{array}$ \\
\hline Collaboration & $2 c$ & $\begin{array}{l}\text { Know how to act with } \\
\text { the rheumatologist, } \\
\text { know what to say, what } \\
\text { to tell, feel free to } \\
\text { suggest adaptations }\end{array}$ & $\begin{array}{l}\text { "I have learned to talk to my doctors about my illness, to give } \\
\text { the right information about the type, timing and spread of the } \\
\text { pain." Mrs B., Patient, RA }\end{array}$ \\
\hline Experimentation & $2 d$ & $\begin{array}{l}\text { Experiments with the } \\
\text { disease and treatment, } \\
\text { know how to draw } \\
\text { conclusions from these } \\
\text { experiments: effects on } \\
\text { oneself and on the } \\
\text { disease }\end{array}$ & $\begin{array}{l}\text { "My wife injects me every } 8 \text { days. Afterwards I manage } \\
\text { myself, sometimes it's every } 10 \text { days. [...] I never reduce as I } \\
\text { know the effects. On the other hand, I have had fun } \\
\text { sometimes pushing at } 10-12 \text { days. Instead of doing it every } \\
8 \text { days, I gain } 4 \text { days because I feel good [...] [my } \\
\text { rheumatologist] she doesn't like it. But I do my own thing." } \\
\text { (Mr. T. patient, SpA) }\end{array}$ \\
\hline Adaptation & $2 e$ & $\begin{array}{l}\text { Deal with the disease } \\
\text { and complications, } \\
\text { know how to cope with } \\
\text { ordinary infections, } \\
\text { manage minor } \\
\text { treatment adjustments } \\
\text { on their own initiative: } \\
\text { treatment schedule or } \\
\text { dosage }\end{array}$ & $\begin{array}{l}\text { "I have the maturity to recognize that... when I have } 4 \text { or } 5 \\
\text { joints "coughing" at the same time I can self-medicate, and I } \\
\text { take anti-inflammatory drugs to break the crisis and try to } \\
\text { restart on my usual pain base..." Mrs M., Patient, RA }\end{array}$ \\
\hline
\end{tabular}


Table 3

Implications for the development of the smartphone app.

\begin{tabular}{|c|c|c|c|c|c|}
\hline $\begin{array}{l}\text { Sub-themes } \\
\text { identified }\end{array}$ & $\begin{array}{l}\text { Qualitative } \\
\text { study } \\
\text { input }\end{array}$ & $\begin{array}{l}\text { Sub- } \\
\text { theme } \\
\text { coding } \\
\text { from the } \\
\text { qualitative } \\
\text { study }\end{array}$ & $\begin{array}{l}\text { Sub-theme } \\
\text { coding } \\
\text { from the } \\
\text { quantitative } \\
\text { study }\end{array}$ & App functionalities & Comments \\
\hline $\begin{array}{l}\text { Information } \\
\text { Relevant } \\
\text { messages }\end{array}$ & Q1, Q2 & $1 a, 2 b$ & 5 & $\begin{array}{l}\text { Periodic messages } \\
\text { on disease and } \\
\text { treatment } \\
\text { Development by } \\
\text { HCPs } \\
\text { Relevant scientific } \\
\text { sources } \\
\text { Situational aids. }\end{array}$ & $\begin{array}{l}\text { Automatic message sending. } \\
\text { The use of situational aids must } \\
\text { depend of the app overall use } \\
\text { because patients will not be } \\
\text { prone to spontaneously search } \\
\text { for safety issues }\end{array}$ \\
\hline $\begin{array}{l}\text { Coordination- } \\
\text { collaboration/ } \\
\text { communication } \\
\text { with doctors and } \\
\text { HCPs }\end{array}$ & Q1, Q2 & $1 b, 2 a, 2 c$ & 1 & $\begin{array}{l}\text { Self-assessment } \\
\text { Comments on } \\
\text { daily life events, } \\
\text { disease activity } \\
\text { and safety } \\
\text { Messages on } \\
\text { communication } \\
\text { with HCPs }\end{array}$ & $\begin{array}{l}\text { Self-assessment should be on a } \\
\text { simple form to be easy to collect } \\
\text { at the time of treatment } \\
\text { administration or on the diary. } \\
\text { Diary easy to visualize by the } \\
\text { HCPs during consultations } \\
\text { Comments on the diary }\end{array}$ \\
\hline $\begin{array}{l}\text { Autonomy, } \\
\text { experimentations }\end{array}$ & Q1 & $\begin{array}{l}1 c, 2 d, 2 e \\
3 a\end{array}$ & 4 & $\begin{array}{l}\text { Self-assessment, } \\
\text { comments, } \\
\text { medical } \\
\text { appointments } \\
\text { Situational aids. }\end{array}$ & $\begin{array}{l}\text { App modalities on recalls, self- } \\
\text { assessment can be monitored by } \\
\text { the patients along with gaining } \\
\text { skills }\end{array}$ \\
\hline $\begin{array}{l}\text { Safety, risks, } \\
\text { dealing with } \\
\text { complications }\end{array}$ & Q1, Q2 & $1 d, 2 e$ & 2 & $\begin{array}{l}\text { Safety checklist at } \\
\text { the time of } \\
\text { treatment } \\
\text { administration } \\
\text { Situational helps } \\
\text { in daily life }\end{array}$ & $\begin{array}{l}\text { App modalities on checklist } \\
\text { should be monitored by the } \\
\text { patients along with gaining skills }\end{array}$ \\
\hline $\begin{array}{l}\text { Adherence } \\
\text { versus safety }\end{array}$ & Q1, Q2 & $1 c, 3 b, 3 c$ & 2,3 & $\begin{array}{l}\text { Treatment recalls, } \\
\text { self-assessment } \\
\text { as a way to } \\
\text { introduce the } \\
\text { safety checklist }\end{array}$ & Ritualize the app use \\
\hline $\begin{array}{l}\text { Influence of } \\
\text { mode of } \\
\text { administration }\end{array}$ & Q2 & $3 c$ & & $\begin{array}{l}\text { Treatment recalls } \\
\text { Checklist }\end{array}$ & $\begin{array}{l}\text { Checklist matching with } \\
\text { bDMARDs needed to be modified } \\
\text { (became optional) }\end{array}$ \\
\hline
\end{tabular}




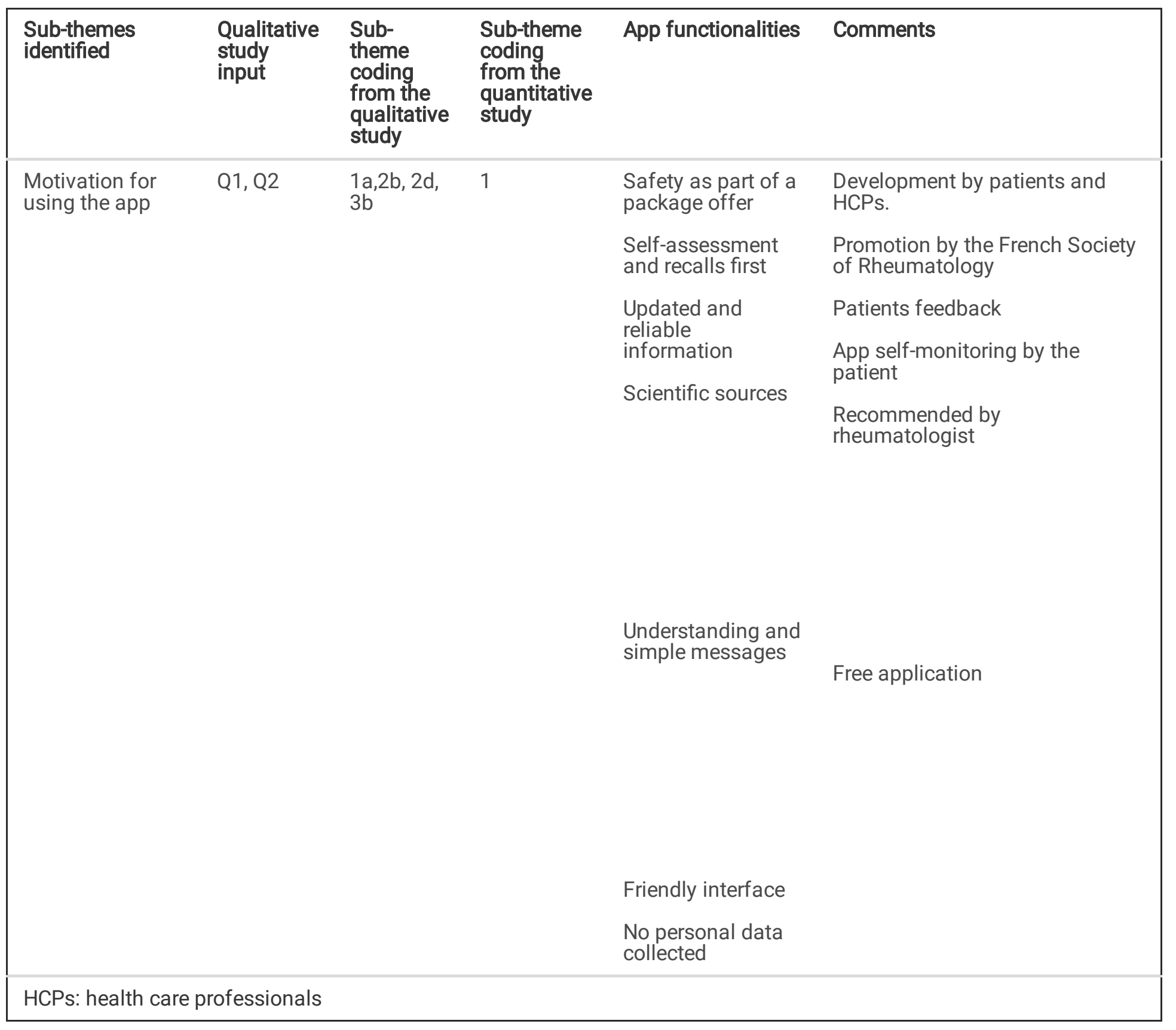

1. Living with IA as a career (Fig. 1).

The Stage 1 duration varied according to patients' profiles and was dominated by the patient's search for causes, looking for information and answers (sub-theme 1a) - "When I was diagnosed I read everything, I wanted to know everything" (Mrs P. Patient, RA) - and finding the right diagnosis and the right doctor: "I was sure that it was that, when I saw the symptoms... Finally, I was happy to put a name to the disease" (Mrs D. Patient, RA).

In Stage 2, the search for treatment involved a close joint effort and partnership between the patient and rheumatologist (sub-theme 1b): "We are partners: we have to fight and to stop the disease." (Mr. T. Patient, SpA). Adjusting the therapeutic approach was needed to control the disease: "Certolizumab had a good effect but not tremendous. We stopped after 18 months [...] Then we tried golimumab; it was an injection every 4 weeks and I said 'be careful, it could be a bit long' and it was a bit long indeed." (Mr. T. Patient, SpA).

In stabilization stage 3, most patients developed routines and habits (sub-themes 1c) with their treatment and could face secondary lack of efficacy: "I found it difficult to tolerate the metho[trexate]: migraines, nausea, food intolerance, it made me 
exhausted the day I took it... and thus a trick consisted in taking it in the evening at bedtime [...] Now I take it on Saturday evening because it bothers me less." (Mrs M. patient, RA)

In Stage 4, the onset of side effects or disease complications (sub-theme 1d) could occur at any point in the disease course. Patients had to cope with the unpredictability of these events such as infections and to handle situations in daily life such as infections or planned surgery: "I had to have herniated disk surgery, I had to stop treatment. Surprise, surprise! you see that it's effective because you start to feel pain again...." (Mr G. Patient, RA). Patients needed to know what the appropriate emergency responses were and what situations required the rheumatologist's intervention or advice: "It got really bad. I got a huge nail infection and had emergency surgery because I let it grow. I sent a picture to my rheumatologist." (Mrs. D. Patient, RA).

2. Patient skills and lay knowledge (Table 2).

To weigh and manage the treatment risks throughout their career, patients needed to develop various types of skills, some of which were related: coordination (sub-theme $2 a$ ), information (sub-theme $2 b$ ), adaptation (sub-theme 2c) experimentation (sub-theme $2 \mathrm{~d}$ ) and adaptation skills (sub-theme $2 \mathrm{e}$ ).

\section{Patient treatment appropriation practices}

Patients were taking control over their medications via multiple adjustments and experiences such as changing their DMARD dosage or administration intervals on their own initiative or trying alternative medicine or food exclusions. Three additional sub-themes emerged:

The treatment ritual (sub-theme 3a). Patients ritualized their subcutaneous administration. Such rituals represented a reflexive moment, only dedicated to themselves and their disease: "Often I take it [methotrexate] and then... I sit down, I take a little 10 minute ritual even if the injection goes very fast. I need to concentrate a little bit and then, as it aches a little bit, I need to rest... sometimes I prefer to do it and then prepare my dinner... so I don't think when it aches ... but yes I like to be alone... (Mrs P. Patient, RA).

- Potential conflict between safety and adherence (sub-theme 3b). During career stage 3, rituals tended to improve adherence but could lead to lack of concern about safety because of habits, over-confidence, and neglect of situations at risk: "Once I hit my tibia with a chainsaw when gardening. We don't remember everything we were told and I did my injection however, so, I was lucky....., despite my 15 stitches I managed to heal well without it getting infected. [My rheumatologist] just reminded me that this kind of mistake should not be done and she was right!... It's just stupid, Etanercept has come into my life and it's a habit and well..., it's fine, but the chainsaw hit [...], I hit the jackpot". (Mr G. Patient, RA)

- Effect of the route of administration. The JAK inhibitor oral route did not modify patients' perceived efficacy and safety of treatment as compared with bDMARDs, but patients' opinions depended on their experience with RA (severity, activity, control) (sub-theme 3c): "That's why, when I was offered baricitinib... I said to myself, 'What is my risk?'. If it is beneficial for me, because ... the tocilizumab starts to decline, the result smells bad. I might gain 1 or 2 years when I will be fine, and then if it gets worse, we'll change [me and the rheumatologist]" (Mrs A. Patient, RA).

4. Implications of qualitative study for the app development (Table 3)

On the whole, from the qualitative study, it appeared useful to provide 6 functionalities with a friendly interface: a safety checklist before treatment administration, aid in daily life situations related to self-management and safety, treatment reminders, global well-being self-assessment, periodic counselling messages, and a diary to note comments and appointments.

\section{Quantitative study}


The quantitative study was carried out from June to August 2016: 344 patients responded to the survey and 331

questionnaires were complete for analysis. Patient demographics and clinical features are in Table 4: $82.8 \%$ were female, $55.7 \%$ had RA, and $62.6 \%$ received methotrexate and 70.4\% bDMARDs; 238 (78\%) patients had a smartphone, 191 (80.9\%) were using apps, but only 61 (32.3\%; 18.4\% overall) were using mhealth apps (Table 5). 
Table 4

Quantitative study. Patient characteristics: demographics, clinical features, information and follow-up $(n=344)$

\begin{tabular}{|c|c|c|}
\hline & $n *$ & Results \\
\hline Female & 331 & $274(82.8)$ \\
\hline Age (years), mean \pm SD & 317 & $53.49 \pm 13.8$ \\
\hline Professional activity & 323 & \\
\hline Currently employed & & $130(40.2)$ \\
\hline Retired & & $103(31.9)$ \\
\hline On sick leave/disability & & $90(27.9)$ \\
\hline Socio-professional status & 326 & \\
\hline Higher & & $93(28.5)$ \\
\hline Lower or intermediate & & $221(67.8)$ \\
\hline Other & & $12(3.7)$ \\
\hline Size of place of residence (no. inhabitants) & 321 & \\
\hline$\geq 200000$ & & $63(19.6)$ \\
\hline $10000-199999$ & & $123(38.3)$ \\
\hline$<10000$ & & $135(42.0)$ \\
\hline Education level & 320 & \\
\hline High school or less & & $119(37.2)$ \\
\hline University & & $201(62.8)$ \\
\hline Member of a patient association (yes) & 331 & $197(59.5)$ \\
\hline Information sources about disease or treatments: & 347 & \\
\hline General practitioner & & 94() \\
\hline Rheumatologist in private care & & 3470 \\
\hline Face-to face/group patient education including nurses & & 1570 \\
\hline Other healthcare practitioner & & 750 \\
\hline Internet/media/ papers & & 2360 \\
\hline Brochures or leaflets/books & & 5040 \\
\hline Type of disease, n (\%) & 298 & \\
\hline
\end{tabular}

Data are $\mathrm{n}(\%)$ unless otherwise indicated.

* Number of available data.

${ }^{1}$ NRS, numeric analog scale. ${ }^{2}$ Coping derived from the RAID score [1]. ${ }^{4}$ Among patients treated with subcutaneous bDMARDs. $\otimes$ High score means bad score.

[1] Gossec L, Paternotte S, Aanerud GJ, Balanescu A, Boumpas DT, Carmona L, et al. Finalisation and validation of the rheumatoid arthritis impact of disease score, a patient-derived composite measure of impact of rheumatoid arthritis: a EULAR initiative. Ann Rheum Dis. 2011;70:935-42 


\begin{tabular}{|c|c|c|}
\hline & $n *$ & Results \\
\hline Rheumatoid arthritis & & $166(55.7)$ \\
\hline Axial or peripheral spondyloarthritis & & $119(39.9)$ \\
\hline Other & & $13(4.4)$ \\
\hline Disease duration (years), mean \pm SD & 291 & $13.81(12.49)$ \\
\hline Treatments & 324 & \\
\hline Current methotrexate & & $203(62.6)$ \\
\hline Current methotrexate duration (years), mean \pm SD & 190 & $8.79(8.09)$ \\
\hline Oral & & $66(32.5)$ \\
\hline Subcutaneous & & $131(64.5)$ \\
\hline Injection by the patient & & $54(41.2)$ \\
\hline Do you sometimes forget to take your methotrexate? (yes) & 181 & $41(22.6)$ \\
\hline Current bDMARD & & $228(70.4)$ \\
\hline Current bDMARD duration (years), mean \pm SD & 222 & $6.91(5.79)$ \\
\hline Subcutaneous & & $169(74.1)$ \\
\hline Injection by the patient (yes) & & $123(72.7)$ \\
\hline Do you sometimes forget to take your bDMARD? ${ }^{4}$ (yes) & 199 & $38(19.1)$ \\
\hline Intravenous & & $57(25.2)$ \\
\hline Both methotrexate and bDMARDs & & $111(34.3)$ \\
\hline 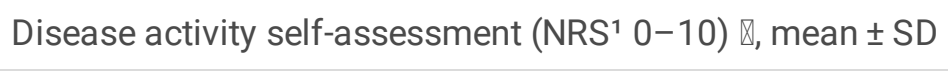 & 331 & $4.43(2.44)$ \\
\hline Coping $^{2}\left(N_{R S}{ }^{1}, 0-10\right) \otimes$, mean \pm SD & 328 & $3.83(2.33)$ \\
\hline \multicolumn{3}{|l|}{ Data are $\mathrm{n}(\%)$ unless otherwise indicated. } \\
\hline \multicolumn{3}{|l|}{ * Number of available data. } \\
\hline \multicolumn{3}{|c|}{$\begin{array}{l}{ }^{1} \mathrm{NRS} \text {, numeric analog scale. }{ }^{2} \text { Coping derived from the RAID score [1]. }{ }^{4} \text { Among patients treated with subcutaneous } \\
\text { bDMARDs. } \otimes \text { High score means bad score. }\end{array}$} \\
\hline \multicolumn{3}{|c|}{$\begin{array}{l}\text { [1] Gossec L, Paternotte S, Aanerud GJ, Balanescu A, Boumpas DT, Carmona L, et al. Finalisation and validation of the } \\
\text { rheumatoid arthritis impact of disease score, a patient-derived composite measure of impact of rheumatoid arthritis: a } \\
\text { EULAR initiative. Ann Rheum Dis. } 2011 ; 70: 935-42\end{array}$} \\
\hline
\end{tabular}

Table 5. Quantitative study: smartphone use, difficulties encountered and information needs $(n=344)$. 
Do you have a SmartPhone (iPhone or Android or Windowsphone)? (yes)

Do you generally use applications on your smartphone? (yes)

Frequency of application use

Once a day

2 to 10 times a day

$>10$ times a day

Do you use health-related applications? (yes)

18961

Have you experienced any difficulties or any questions about your treatment? $\mathrm{\text {(yes) }}$

Facing these difficulties or questions, did you feel the need for advice or counselling?

Mark below the situation(s) that you have encountered or you have had problems with: 312 प

Fever or infection

Vaccines

Surgery

Storage/travelling

Fatigue

Wish to stop treatment

45

Dental care

43

Drug administration

Forgotten dose or missed dose

Gastrointestinal symptoms

Pulmonary symptoms

Pregnancy planning

Other symptoms and adverse effects

What other information would be useful to you? Indicate without restriction your opinion on other possible uses of the application. ${ }^{*}$ 
* Number of available data.

$\square$ Among total population. $\square$ Among individuals having a smartphone. $\square$ Among individuals using applications. ૫ Among individuals facing difficulties. $\square$ In total. 607 situations were collected. The \% is calculated in proportion to the total number of situations. Self-monitoring (pain, difficulties, biologic monitoring) (10 items), management of adverse effects (8), holistic management, improve daily life (6), new treatments ( 3), patient doctor communication(2), chat box (2), adherence (1)

Whether or not they had used apps, $70.5 \%$ of the patients reported having questions or encountering difficulties with their treatment and $67.5 \%$ had needed help or advice. The main issues were related to safety: infections, vaccines, surgery, storage/travel, dental care (Table 5). Other issues such as self-administration or missed doses were more rarely reported. Fatigue and the wish to stop treatment were themes related to patients' coping with their disease.

Among app users who answered the question $(n=211), 86.8 \%(n=177)$ would willingly use an app to manage their treatment (51\% strongly agreed, $35.8 \%$ rather agreed) and $64.4 \%(n=112)$ would accept the app only on their rheumatologist's recommendation (Table 6). Patients interested in the app were more frequently younger than those who would not use the app [age 48.4 years $( \pm 12 \mathrm{SD}$ ) vs 54 years $( \pm 12 \mathrm{SD}), \mathrm{p}<0.05$ ], not members of a patient association $(66.7 \%$ vs $45.4 \%, p<0.05)$ and lived in medium-sized than other sized cities $(p<0.01)$. We found no association with other sociodemographic characteristics, level of education, type/duration of arthritis or knowledge. 
Quantitative study: potential use of the app, patients' approval' ${ }^{1}$, implications for app $\operatorname{development}^{2}(\mathrm{n}=236)$

\begin{tabular}{|c|c|c|c|c|c|}
\hline Potential use (sub-theme no. in Table 3) & $n *$ & $\begin{array}{l}\text { Totally } \\
\text { agree }\end{array}$ & $\begin{array}{l}\text { Rather } \\
\text { agree }\end{array}$ & $\begin{array}{l}\text { Rather not } \\
\text { agree }\end{array}$ & $\begin{array}{l}\text { Not at all } \\
\text { agree }\end{array}$ \\
\hline I would willingly use this application & 204 & $\begin{array}{l}104 \\
(51.0)\end{array}$ & $\begin{array}{l}73 \\
(35.8)\end{array}$ & $13(6.4)$ & $14(6.9)$ \\
\hline $\begin{array}{l}\text { I would only accept the app on the recommendation of my } \\
\text { rheumatologist (subtheme 1) }\end{array}$ & 211 & $\begin{array}{l}49 \\
(28.2)\end{array}$ & $\begin{array}{l}63 \\
(36.2)\end{array}$ & $27(15.5)$ & $35(20.1)$ \\
\hline \multicolumn{6}{|l|}{ I would use it: } \\
\hline $\begin{array}{l}\text { In case I had symptoms that would require stopping my } \\
\text { treatment (subtheme 2) }\end{array}$ & 211 & $\begin{array}{l}101 \\
(47.9)\end{array}$ & $\begin{array}{l}72 \\
(34.1)\end{array}$ & $22(10.4)$ & $16(7.6)$ \\
\hline To know the situations at risk with my treatment (subtheme 2) & 211 & $\begin{array}{l}113 \\
(53.5)\end{array}$ & $\begin{array}{l}83 \\
(39.3)\end{array}$ & $6(2.8)$ & $9(4.3)$ \\
\hline To have a treatment reminder (subtheme 3) & 202 & $\begin{array}{l}106 \\
(52.5)\end{array}$ & $\begin{array}{l}56 \\
(27.2)\end{array}$ & $23(11.4)$ & $17(8.2)$ \\
\hline $\begin{array}{l}\text { To know what to do in case of missed doses or forgotten } \\
\text { treatment (subtheme 4) }\end{array}$ & 199 & $\begin{array}{l}86 \\
(43.2)\end{array}$ & $\begin{array}{l}69 \\
(34.7)\end{array}$ & $27(13.6)$ & $17(8.5)$ \\
\hline $\begin{array}{l}\text { To have a safety checklist before treatment administration } \\
\text { (subtheme 2) }\end{array}$ & 201 & $\begin{array}{l}82 \\
(40.8)\end{array}$ & $\begin{array}{l}74 \\
(36.2)\end{array}$ & $27(13.3)$ & $18(9.0)$ \\
\hline To recall on how to make self-injections (subtheme 5$)^{3}$ & 176 & $\begin{array}{l}61 \\
(34.6)\end{array}$ & $\begin{array}{l}56 \\
(31.8)\end{array}$ & $22(12.5)$ & $37(21.0)$ \\
\hline To have a reminder on monitoring tests (subtheme 4) & 205 & $\begin{array}{l}104 \\
(50.7)\end{array}$ & $\begin{array}{l}80 \\
(39.2)\end{array}$ & $8(3.9)$ & $13(6.3)$ \\
\hline To get information on reliable websites (subtheme 5) & 211 & $\begin{array}{l}101 \\
(47.9)\end{array}$ & $\begin{array}{l}80 \\
(37.9)\end{array}$ & $18(8.5)$ & $12(5.7)$ \\
\hline \multicolumn{6}{|l|}{ Data are $\mathrm{n}(\%)$ unless otherwise indicated. } \\
\hline \multicolumn{6}{|l|}{ * Number of available data. } \\
\hline
\end{tabular}

Potential uses of the app are presented in Table 6 according to implications for the app in Table 3. The app would mainly be used to find out what to do in case of risk situations $(92.8 \%, \mathrm{n}=196$ [strongly or rather agreed]) or to find out what symptoms would require stopping treatment $(82 \% ; n=173)$. It could also be used as a treatment reminder $(79.7 \% ; n=162)$, a reminder of the monitoring tests $(89.9 \% ; n=184)$ or as a safety checklist before treatment administration $(77 \%, n=156)$.

\section{Construction of the first version of HIBOOT}

The construction of the app (Step 2) is presented in supplementary material $\mathbf{5}$ and $\mathbf{6}$. The steering committee and the French Society of Rheumatology decided that no personal information would be collected. Consequently, the app was constructed as a self-administered and self-management information app and was not registered as a medical device. Patient data were not to be communicated to rheumatologists or general practitioners. However, patients could communicate with their physicians about their data or app use during physical consultations or by Internet with screenshots. The app was free of charge and the chosen look was a friendly companion called HIBOOT (OWL in English) that interacted with the user. The owl evokes a watchful animal, attentive to safety, and its small size can make it a companion (HIBOOT features in supplementary material 5). The first version included functionalities related mainly to safety of the available DMARDs, treatment adherence and general information on disease and treatments. (supplementary material 6) 


\section{Implementation technology}

The HIBOOT app is a hybrid app. Development was made with the javascript front-end framework AngularJS, then packaged by using Cordova. We used an lonic library to create the user interface. The lonic library runs on a wide range of Android and iPhone devices. Content of the app was managed by a headless content management system named Prismic. User data and parameters are stored within the app.

\section{The launch campaign}

The launch campaign (Step 3) included e-mails to the French rheumatologists on the mailing list of the French Society of Rheumatology, monthly newsletters form the Club Rhumatismes Inflammation network devoted to IA and DMARDs (www.cri-net.com), and flyers and posters printed for outpatient clinic offices for private rheumatologists and rheumatology departments. Advertising was produced for the front page of the French Society of Rheumatology website and for social networks (Facebook, Twitter@AppliHiboot) as well as on patient association's websites and Facebook/Twitter accounts. A video was posted on YouTube.

\section{Users' feedback}

The users' feedback (Step 4) showed 2 usage types: 1) a regular use by patients who had adopted the HIBOOT companion and demanded more functionalities and 2) a more punctual use on specific questions with the need for quick answers. The functionalities appreciated by the patients were the reminder system and understandable and reliable messages. The independent scientific content was appreciated by both patients and rheumatologists. However, the navigation system needed improvement and the checklist was considered too repetitive by some. Patients were willing to have a more holistic management of their disease by using the personal diary and to have an optional use of the treatment reminder functionality and the checklist.

\section{Current version}

The current version of HIBOOT (Step 6) (Table 7 and supplementary material 6) implemented additional DMARDs including anti-IL-17, JAK inhibitors and biosimilars; updated all DMARDs; and added more functionalities such as a diary to note medical appointments or personal comments, events and memos to prepare for medical consultations. After user feedback, a HIBOOT website was developed (www.hiboot.fr, 02.16.2021) to present the safety messages, with the other functionalities remaining only available on the app. 
Table 7

Information on daily situations/symptoms and patient queries from the app from March to November 2020

\begin{tabular}{|c|c|c|c|c|c|c|c|}
\hline Situations/symptoms & $\begin{array}{l}\text { Availability } \\
\text { in first } \\
\text { version }\end{array}$ & $\begin{array}{l}\text { Availability } \\
\text { in current } \\
\text { version }\end{array}$ & $\begin{array}{l}\text { Key } \\
\text { words } \\
\text { in } \\
\text { current } \\
\text { version } \\
\text { (no.) }\end{array}$ & $\begin{array}{l}\text { Availability } \\
\text { of general } \\
\text { information } 1\end{array}$ & $\begin{array}{l}\text { Availability } \\
\text { of specific } \\
\text { information } 2\end{array}$ & $\begin{array}{l}\text { Patients' } \\
\text { queries }{ }^{3} \\
\text { (no.) }\end{array}$ & $\begin{array}{l}\text { Ranking } \\
\text { of the } \\
\text { query } \\
\text { types }\end{array}$ \\
\hline $\begin{array}{l}\text { Total } \\
\text { situations/symptoms } \\
\text { (no.) }\end{array}$ & 19 & 34 & & & & 18022 & \\
\hline Total key words (no.) & & & 271 & & & & \\
\hline Skin abnormalities & & & 49 & & & 3263 & 1 \\
\hline Sensitivity to sunlight & • & - & 12 & • & - & 1011 & \\
\hline Skin reactions, allergies & • & - & 15 & • & - & 1304 & \\
\hline Burns & - & - & 5 & • & - & 185 & \\
\hline Wounds & • & $\cdot$ & 8 & • & - & 604 & \\
\hline Mycosis/candidosis & & $\cdot$ & 9 & • & $\cdot$ & 159 & \\
\hline Infections & & & 64 & & & 3082 & 2 \\
\hline Influenza & • & $\cdot$ & 11 & - & • & 540 & \\
\hline Bronchitis, pneumonia & • & - & 12 & • & - & 446 & \\
\hline Gastroenteritis & - & $\cdot$ & 9 & - & $\cdot$ & 379 & \\
\hline Urinary tract infections & • & - & 12 & • & - & 328 & \\
\hline $\begin{array}{l}\text { Herpes, chickenpox, } \\
\text { shingles }\end{array}$ & • & $\cdot$ & 7 & • & $\cdot$ & 130 & \\
\hline Vaccines & • & - & 23 & - & • & 435 & \\
\hline COVID-19* & & $\cdot$ & 2 & • & & 824 & \\
\hline Dental care & • & $\cdot$ & 16 & • & $\cdot$ & 2701 & 3 \\
\hline $\begin{array}{l}\text { Questions about } \\
\text { treatment }\end{array}$ & & & 13 & & & 2129 & 4 \\
\hline Forgetting treatment & - & $\cdot$ & 7 & • & $\cdot$ & 945 & \\
\hline Stopping treatment & - & - & 2 & - & - & 566 & \\
\hline Drug Interactions & - & $\cdot$ & 4 & $\cdot$ & $\cdot$ & 618 & \\
\hline Storage/travel & & & 22 & & & 1769 & 5 \\
\hline Storage at home & - & $\cdot$ & 5 & $\cdot$ & $\cdot$ & 451 & \\
\hline Carrying treatment & • & - & 8 & - & - & 624 & \\
\hline
\end{tabular}

${ }^{1}$ information common to all DMARDs. ${ }^{2}$ Information depending on the type of DMARDs. ${ }^{3}$ data collected in Google analytics.

- availability

*Information on COVID-19 could not be pursued on Android after June 2020 because of cancellation by Google. 


\begin{tabular}{|c|c|c|c|c|c|c|c|}
\hline Situations/symptoms & $\begin{array}{l}\text { Availability } \\
\text { in first } \\
\text { version }\end{array}$ & $\begin{array}{l}\text { Availability } \\
\text { in current } \\
\text { version }\end{array}$ & $\begin{array}{l}\text { Key } \\
\text { words } \\
\text { in } \\
\text { current } \\
\text { version } \\
\text { (no.) }\end{array}$ & $\begin{array}{l}\text { Availability } \\
\text { of general } \\
\text { information } 1\end{array}$ & $\begin{array}{l}\text { Availability } \\
\text { of specific } \\
\text { information }{ }^{2}\end{array}$ & $\begin{array}{l}\text { Patients' } \\
\text { queries } \\
\text { (no.) }\end{array}$ & $\begin{array}{l}\text { Ranking } \\
\text { of the } \\
\text { query } \\
\text { types }\end{array}$ \\
\hline Going on a journey & $\cdot$ & $\cdot$ & 9 & $\cdot$ & $\cdot$ & 694 & \\
\hline $\begin{array}{l}\text { Libido/erectile } \\
\text { dysfunction }\end{array}$ & & $\cdot$ & 8 & $\cdot$ & $\cdot$ & 1698 & 6 \\
\hline Surgery & $\cdot$ & $\cdot$ & 15 & $\cdot$ & $\cdot$ & 805 & 7 \\
\hline Pregnancy & $\cdot$ & $\cdot$ & 11 & $\cdot$ & $\cdot$ & 638 & 8 \\
\hline Thermal/spa therapy & & $\cdot$ & 5 & $\cdot$ & & 599 & 9 \\
\hline $\begin{array}{l}\text { Blood sample } \\
\text { abnormalities }\end{array}$ & & & 26 & & & 466 & 10 \\
\hline Blood abnormalities & & $\cdot$ & 11 & $\cdot$ & $\cdot$ & 171 & \\
\hline $\begin{array}{l}\text { Increase in cholesterol } \\
\text { levels }\end{array}$ & & $\cdot$ & 6 & $\cdot$ & $\cdot$ & 86 & \\
\hline $\begin{array}{l}\text { Liver/hepatic } \\
\text { abnormalities }\end{array}$ & & $\cdot$ & 9 & $\cdot$ & $\cdot$ & 209 & \\
\hline $\begin{array}{l}\text { Gastrointestinal } \\
\text { symptoms }\end{array}$ & & & 20 & & & 445 & 11 \\
\hline Digestive disorders & & $\cdot$ & 10 & $\cdot$ & $\cdot$ & 211 & \\
\hline Blood in the stools & & $\cdot$ & 5 & $\cdot$ & & 57 & \\
\hline Colonoscopy/fibroscopy & & $\cdot$ & 5 & $\cdot$ & & 177 & \\
\hline Other symptoms & & & 22 & & & 427 & 12 \\
\hline Fatigue & & $\cdot$ & 1 & $\cdot$ & $\cdot$ & 147 & \\
\hline Fractures & & $\cdot$ & 5 & $\cdot$ & $\cdot$ & 48 & \\
\hline Cancers & & $\cdot$ & 8 & $\cdot$ & & 81 & \\
\hline Dizziness & & $\cdot$ & 4 & $\cdot$ & & 110 & \\
\hline High blood pressure & & $\cdot$ & 4 & $\cdot$ & $\cdot$ & 41 & \\
\hline \multicolumn{8}{|c|}{$\begin{array}{l}\text { 1information common to all DMARDs. }{ }^{2} \text { Information depending on the type of DMARDs. }{ }^{3} \text { data collected in Google } \\
\text { analytics. }\end{array}$} \\
\hline \multicolumn{8}{|l|}{ - availability } \\
\hline
\end{tabular}

\section{App assessment}

The app assessment is presented in Figs. 2 and 3 and Table 7. The app was installed 20,500 times from 2017 to 2020 from both stores (Android and iOS) with an increasing curve (Fig. 2). The number of app removals was 2870 . The number of regular users was 4328 (i.e., approximately $21 \%$ of the installations) (Fig. 3) with 18,000 requests from March to November 2020 on daily life situations (Table 7). The types of situations sought by users (Table 7) corresponded to those identified in preliminary studies, such as infections, dental care, and storage/travel. However, the first troublesome symptoms searched in the app were skin allergies, injection site reactions and tattoos and piercing, which had not been identified before 
development. Questions on libido ranked in sixth position, added after users' feedback, as well as thermal/spa therapy. The most-used functionalities were the checklist (3.97 views/month/users), diary (3.18 views/month/users) and daily/safety situations (3.38 views/month/users) (supplementary material 7).

In March 2020, a peak in use concerned COVID-19. However, information on COVID-19 could not be pursued on Android after June 2020 because of cancellation by Google with the claim that HIBOOT was not a government app.

The scores at both stores have been 4.4/5 (supplementary material 8).

\section{Discussion}

Here we describe the development of the HIBOOT app dedicated to safety, self-assessment and medication adherence for patients with IA.

To our knowledge, no app of this nature is currently available.

The design and development followed a step-by-step strategy matched with patients' needs and opinions by using 2 qualitative studies, one quantitative study and on-going user feedback to improve versions over time.

The final device contains 6 functionalities, including a safety checklist, safety aids in everyday life, treatment reminders, simple self-assessment, periodic educational posts, and a diary to note comments, appointments and other medications. HIBOOT is a free app. Real-life use assessment showed a still-increasing number of current users, 4300 so far, and good scores at stores.

The original design focused on disseminating safety messages and reinforcing safe behaviors. For this, an in-depth study on patients' habits and appropriation practices with their treatment was necessary.

A first finding was that the maintenance of patients' safety skills could conflict with good adherence to their DMARDs by habits and over-confidence. Therefore, many patients would not spontaneously search safety information even though a reliable app was available. In other words, because the app use in real-life was an imperative goal, patients had to be attracted by motivations other than safety alone. Medication reminders and patient self-assessment at the time of ritualizing DMARD self-administration were implemented, such as periodic incentives to use the safety checklist. Including reminders was also of interest because medication adherence in IA needs to be improved [35.36] and the benefit of reminders has been shown by short message service (SMS) systems in RA [37] or by apps for other chronic conditions [38]. In this, HIBOOT provides treatment recalls similar to the literature [10]. However, the systematic use of the checklist was counterproductive for some patients as interviews with users showed, so the checklist was secondarily made optional. The treatment recalls were also challenged by the introduction of JAK inhibitors whose oral and daily administration could modify patients' habits. The second qualitative study concluded that the app design did not need critical reappraisal in this regard.

The preliminary studies showed that reliable information was important for patients, which was consistent with other studies [39.40]. As expected, how to manage complications and potential risks emerged (e.g., in the case of infections or surgery). However, other features of self-management were found essential to consider; indeed, experiments and medication adjustments were current practices for people with IA. The app should be able to answer this kind of question, such as missed doses or even the wish to stop or taper DMARDs. Moreover, patients' concerns widely exceeded the core set of safety information usually provided by healthcare professionals. This observation appeared with the user feedback after launch: minor though troublesome side effects such as skin problems or more intimate sexual matters needed to be added. It also became clear that responding to these requests was necessary to ensure the sustainability of the app use.

HIBOOT app does not contain monitoring of patient-related outcomes as described in other apps [7]. Although studies have shown that patients favour self-monitoring health or disease activity [39-41] and many people with IA would agree to share

Page 20/27 
their mobile app data for research purposes or regularly enter data [40], self-monitoring was suggested by only 10 patients in our quantitative study and thus was not retained. However, no specific question was asked about self-management in the survey, which might have underestimated the patients' interest. Instead, we provided a friendly interface for self-assessment and the opportunity to enter comments to be shared with the rheumatologist or physician.

The HIBOOT development has strengths. The tailored strategy and the continuous attention to user feedback allowed for corrections from the first to the current version and content enrichment. However, HIBOOT was not spared from "bugs" and had to be revised, particularly on Android. The HIBOOT app meets 6 of the 10 EULAR recommendations for app development for people with IA [11]: to date, scientifically justifiable, user acceptable and evidence-based information; relevant and tailored to the people individual needs; involvement of patients and relevant healthcare providers in design and development; transparency of the app's developer, funding source, content validation process, version updates and data ownership; attention to data protection; and facilitation of patient-healthcare provider communication.

The assessment of the number of installations and regular users is also a strength because this is seldom described in the literature, as well as the collection of used functionalities and people's queries. The latter analysis provided a broad overview of patients' concerns about daily and safety issues. The 20,500 installations may appear small as compared with the IA prevalence in France, estimated at 400,000 people for both RA and SpA [42-43], which indicates that approximately $5 \%$ of patients installed the HIBOOT app. However, this number seems substantial as compared with other apps for people with IA. For instance, among 3 apps for physical activity identified by Bearne et al. [8], one was installed by 1000 people with RA and one by 500 people, and information was not available for the last one. The number of installations is also to be compared with the still low use of mhealth apps: $4.1 \%$ of the IA population used mhealth apps in Germany [40], and $4.6 \%$ of RA patients used specific mhealth apps for their disease in France [44]. In our quantitative study, 18.4\% of IA people used mhealth apps in general, whereas in another international study, $20 \%$ of patients with rheumatic and musculoskeletal diseases used a specific app for self-management [39]. These differences were probably due to recruitment bias (countries, population) and also the type of survey, because one published study [39] and ours obtained responses via the Internet, whereas the other 2 were paper-based [40.44]. This observation may indicate that an important proportion of French people with IA was interested in installing HIBOOT, probably close to the whole population who already used mhealth apps (i.e, 5\%). The HIBOOT app life is longer than most published apps: some have shown a rapid decrease in use over a 4-week period [7], $75 \%$ people had stopped using them after 3 months [39] and only $5 \%$ of apps for rheumatic and musculoskeletal diseases were still available 2 years after their launch [4].

Limitations

With regard to EULAR recommendations, HIBOOT has some limitations because it is not a medical device collecting data for research or self-monitoring. As mentioned above, this aspect did not emerge from our preliminary studies but may have been underestimated. Not specifically checking health literacy was also a limitation, because another study mentioned this as an important barrier [40]. Concerning users' assessment, we looked for only star ratings at the stores. We are aware that this is only very broad information that poorly reflects the true app quality as compared with other evaluation tools, MARS [10] being the most commonly used [45]. The star systems may over-rate the app quality for two-thirds of users [46]. Therefore, future assessment of the benefit of HIBOOT as to its features, safety and adherence will be needed.

In conclusion, HIBOOT is a free app dedicated to safety issues, adherence and self-assessment for patients with IA. The app has good usage and was developed according to international recommendations for people with IA. Further studies will be needed to assess the benefits of this app. However, the still-increasing number of current users seems a surrogate marker of its utility.

\section{Declarations}

Ethics and consent to participate

Page 21/27 
Participants of the qualitative research were informed of the study objectives and schedule and expressed their nonopposition according to local recommendations. The research was approved by an ethics committee (CPP no. 19.07.02.68617, Comité de Protection des Personnes) and was declared to the commission for data collection, the Commission Informatique et Liberté (no. 2,214,586). Regarding the quantitative survey, patients who were given the Internet link by the rheumatologists were orally informed of the objectives of the study. Their participation was not monitored. Therefore, approval by an ethics committee was not requested according to local recommendations.

Consent for publication

Consent to publication was included in the non-opposition form.

Availability of data and materials

The datasets used and/or analysed during the qualitative and quantitative studies are available from the corresponding author on reasonable request.

Funding

This study was funded by the French Society of Rheumatology. The French Society of Rheumatology received an institutional grant from (alphabetical orders): Abbvie, Biogen, Janssen, Lilly, Merck Sharp \& Dohme, Novartis, Nordic Pharma, Roche France and Pfizer for the development of a mhealth tool for patients with inflammatory arthritis. The pharmaceutical companies were not involved in the App general design or development, study design, data collection, interpretation or decision to publish. The grant was used to conduct qualitative and quantitative studies, the app development and communication.

Promotor: French Society of Rheumatology

Disclosures of Interest

$C B, T P, A L, C V, G D, P B, S D, F T, D L, L G, F A L, M A, S P$ and JS declare no competing interests in relation is this study.

SG, FM were paid by Unknowns Research department for their contribution to the study.

GM, JLC, MQ, were employed by Unknowns Conseil en stratégie et innovation, Paris, France

HJ and LB are owners of Unknowns Conseil en stratégie et innovation, Paris, France

Authorship

Contributors:

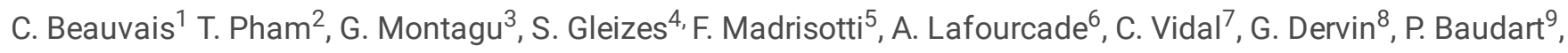
S. Desouches ${ }^{10}$, F. Tubach ${ }^{11}$, J. Le Calvez ${ }^{12}$, M. de Quatrebarbes ${ }^{13}$, D. Lafarge ${ }^{14}$, L. Grange ${ }^{15}$, F. Alliot-Launois ${ }^{16}, \mathrm{H}_{\text {. }}$

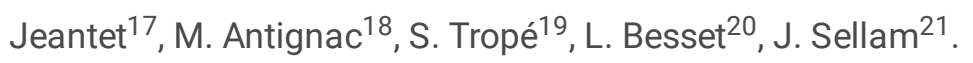

Study design: authors 1,2,17,20,21. Qualitative studies: authors $1,2,3,17,18,19,20,21$ for design and schedule, authors 1,2,19,21 for selecting participants, authors 3,4,5 for interviews and data analysis, authors 1 and 3 for results synthesis and presentation. Quantitative study authors 1,2,11,19,21 for design, authors 14, 12,19 for collecting data, author 1 and 6 for data analysis and interpretation. App development: authors 1,2,3,7, 8, 9, 10, 12, 13, 15, 16, 17, 19, 20, 21. App assessment: authors 1,3,17,20,21. Manuscript writing: author 1,3. Reviews of the first and final draft of the paper (all authors). All authors revised the paper critically for intellectual content and approved the final version. All authors agree to be accountable for the 
work and to ensure that any questions relating to the accuracy and integrity of the paper are investigated and properly resolved.

Acknowledgements.

We thank all patients who participated the qualitative and quantitative studies; patients and rheumatologists who participated in the users' feedback and app improvements; Mme Nathalie Robert from the association Spondyl(0)action for users' feedback; Mahed Iqbal (Unknowns) and Alexandre Galatioto (Unknowns) for development contribution; Damien Carnet (ANDAR) for posting the quantitative study questionnaire; Laura Smales for reviewing the English version; and Frédéric Lioté, Hôpital Lariboisière, Paris, who contributed to patient recruitment in Q2.

\section{References}

1. World Health Organization. 2016. From innovation to implementation. eHealth in the WHO European Region. http://www.euro.who.int/_data/assets/pdf_file/0012/302331/From-Innovation-to-Implementation-eHealth-ReportEU.pdf (2nd January 2020).

2. Mollard E, Michaud K. Mobile Apps for Rheumatoid Arthritis: Opportunities and Challenges. Rheum Dis Clin North Am. 2019;45:197-209.

3. Mollard E, Michaud K. Self-Management of Rheumatoid Arthritis: Mobile Applications. Curr Rheumatol Rep. 2020;23:2. 10.1007/s11926-020-00968-7.. ,. doi.

4. Najm A, Gossec L, Weill C, Benoist D, Berenbaum F, Nikiphorou E. Mobile Health Apps for Self-Management of Rheumatic and Musculoskeletal Diseases: Systematic Literature Review. JMIR Mhealth Uhealth. 2019;7:e14730.

5. Luo D, Wang P, Lu F, Elias J, Sparks JA, Lee YC. Mobile Apps for Individuals With Rheumatoid Arthritis: A Systematic Review. J Clin Rheumatol. 2019;25:133-41.

6. Grainger R, Townsley H, White B, Langlotz T, Taylor WJ. Apps for people with rheumatoid arthritis to monitor their disease activity: a review of apps for best practice and quality. JMIR Mhealth Uhealth. 2017;5:e7.

7. Seppen BF, Wiegel J, L'ami MJ, Duarte dos Santos Rico S, Catarinella FS, Franktien Turkstra1 F et al. Feasibility of SelfMonitoring Rheumatoid Arthritis With a Smartphone App: Results of Two Mixed-Methods Pilot Studies. JMIR Form Res 2020;4:e20165.

8. Bearne LM, Sekhon M, Grainger R, La A, Shamali M, Amirova A et al. Smartphone Apps Targeting Physical Activity in People With Rheumatoid Arthritis: Systematic Quality Appraisal and Content Analysis. JMIR Mhealth Uhealth.. 2020;8:e18495. doi: 10.2196/18495.

9. Revenäs Å, Opava CH, Ahlén H, Brusewitz M, Pettersson S, Pernilla Åsenlöf P. Mobile internet service for selfmanagement of physical activity in people with rheumatoid arthritis: evaluation of a test version. RMD Open. 2016;2:e000214. doi:10.1136/rmdopen-2015-000214. eCollection 2016.

10. Knitza J, Tascilar K, Messner EM, Meyer M, Vossen D, Pulla A. German Mobile Apps in Rheumatology: Review and Analysis Using the Mobile Application Rating Scale (MARS). JMIR Mhealth Uhealth. 2019;7:e14991.

11. Najm A, Nikiphorou E, Kostine M, Richez C, Pauling J, Finckh A, et al. EULAR points to consider for the development, evaluation and implementation of mobile health applications aiding self-management in people living with rheumatic and musculoskeletal diseases. RMD Open. 2019;13;5:e001014.

12. Zangi HA, Ndosi M, Adams J, Andersen L, Bode C, Boström C, et al. EULAR recommendations for patient education for people with inflammatory arthritis. Ann Rheum Dis. 2015;74:954-62.

13. Daien C, Hua C, Gaujoux-Viala C, Cantagrel A, Dubremetz M, Dougados M, et al. Update of French Society for Rheumatology Recommendations for Managing Rheumatoid Arthritis. Joint Bone Spine. 2019;86:135-50.

14. Smolen JS, Landewé R, Bijlsma J, Burmester G, Dougados M, Kerschbaumer A, et al. EULAR recommendations for the management of rheumatoid arthritis with synthetic and biological disease-modifying antirheumatic drugs: 2019 
update. Ann Rheum Dis. 2020;79:685-99.

15. Wendling D, Lukas C, Prati C, Claudepierre P, Gossec L, Goupille P, et al. 2018 update of French Society for Rheumatology (SFR) recommendations about the everyday management of patients with spondyloarthritis. Joint Bone Spine. 2018;85:275-84.

16. van der Heijde D, Ramiro S, Landewé R, Baraliakos X, Van den Bosch F, Sepriano A, et al. 2016 update of the ASASEULAR management recommendations for axial spondyloarthritis. Ann Rheum Dis. 2017;76:978-91.

17. Gossec L, Baraliakos X, Kerschbaumer A, de Wit M, Mclnnes I, Dougados M, et al. EULAR recommendations for the management of psoriatic arthritis with pharmacological therapies: 2019 update. Ann Rheum Dis. 2020;79:680-2.

18. Sepriano A, Kerschbaumer A, Smolen J, van der Heijde D, Dougados M, van Vollenhoven R, et al. Safety of synthetic and biological DMARDs: a systematic literature review informing the 2019 update of the EULAR recommendations for the management of rheumatoid arthritis. Ann Rheum Dis. 2020;79:760-70.

19. Sepriano A, Regel A, van der Heijde D, Braun J, Baraliakos X, Landewé R, et al. Efficacy and safety of biological and targeted-synthetic DMARDs: a systematic literature review informing the 2016 update of the ASAS/EULAR recommendations for the management of axial spondyloarthritis. RMD Open. 2017 27;3:e000396. doi: 10.1136/rmdopen-2016-000396. eCollection 2017.

20. Furer V, Rondaan C, Heijstek MW, Agmon-Levin N, van Assen S, Bijl M, et al. 2019 update of EULAR recommendations for vaccination in adult patients with autoimmune inflammatory rheumatic diseases. Ann Rheum Dis. 2020;79:39-52.

21. Beauvais C, Fayet F, Rousseau A, Sordet C, Pouplin S, Maugars Y, et al. Efficacy of a nurse-led patient education intervention in promoting safety knowledge and skills of patients with inflammatory arthritis $(\mathrm{IA})$ treated with biologics: a randomized controlled trial. Ann Rheum Dis, volume 78, supplement 2, year 2019, page A1441.

22. Gutermann L, Dumas S, Lopez-Medina C, Boissinot L, Camille Cotteret C, Perut V, et al. Impact of a pharmacist-led programme on biologics knowledge and adherence in patients with spondyloarthritis. Clin Exp Rheumatol, 2020 Oct 9. Online ahead of print.

23. Niederman K, Fransen J, Knols R, Uebelhart D. Gap between short and long-term effects of patient education in rheumatoid arthritis patients: a systematic review. Arthritis Rheum. 2004;51:388-98.

24. Aletaha D, Neogi T, Silman AJ, Funovits J, Felson DT, Bingham 3rd CO, et al. 2010 rheumatoid arthritis classification criteria: an American College of Rheumatology/European League Against Rheumatism collaborative initiative. Arthritis Rheum. 2010;62:2569-81.

25. Rudwaleit M, van der Heijde D, Landewé R, Listing J, Akkoc N, Brandt J, et al. The development of Assessment of SpondyloArthritis international Society classification criteria for axial spondyloarthritis (part II): validation and final selection. Ann Rheum Dis. 2009 Jun;68(6):777-83. doi:10.1136/ard.2009.108233.

26. Rudwaleit M, van der Heijde D, Landewé R, Akkoc N, Brandt J, Chou CT, et al. The Assessment of SpondyloArthritis International Society classification criteria for peripheral spondyloarthritis and for spondyloarthritis in general. Ann Rheum Dis. 2011 Jan;70(1):25-31. doi:10.1136/ard.2010.133645.

27. Tong A, Sainsbury P, Craig J. Consolidated criteria for reporting qualitative research (COREQ): a 32-item checklist for interviews and focus groups. Int J Qual Health Care. 2007;19:349-57.

28. Pham T, Fautrel B, Gottenberg JE, Goupille P, Hachulla E, Masson C, et al. Rheumatic Diseases \& Inflammation Group (Club Rhumatismes et Inflammation, CRI) of the French Society for Rheumatology (Société Française de Rhumatologie, SFR). Rituximab (MabThera) therapy and safety management. Clinical tool guide.

29. Joint Bone S. 2008;75Suppl 1:S1-99.

30. Pham T, Claudepierre P, Constantin A, de Bandt M, Fautrel B, Gossec L, et al. Tocilizumab: therapy and safety management. Joint Bone Spine. 2010;77(Suppl 1):3-100.

31. Pham T, Bachelez H, Blacher JM, Bouhnik J, Pascal Claudepierre Y. P et al. alpha antagonist therapy and safety monitoring. Joint Bone Spine. 2011;78(Suppl 1):15-85. 
32. Pham T, Bachelez H, Blacher JM, Claudepierre J, Constantin P. A et al. Abatacept therapy and safety management. Joint Bone Spine. 2012;79(Suppl 1):3-84.

33. Richez C, Morel J, Cornec D, Daïen C, Goupille P, Lazaro E, et al. Practical management of patients on Janus kinase inhibitor (JAKi) therapy: Practical fact sheets drawn up by the Rheumatism and Inflammation Club (CRI), a group endorsed by the French Society for Rheumatology (SFR). Joint Bone Spine. 2019;86(Suppl 1):eS2-103.

34. Curtis JR, Xie F, Yun H, Bernatsky S, Winthrop K. Real-world comparative risks of herpes virus infections in tofacitinib and biologic-treated patients with rheumatoid arthritis. Ann Rheum Dis. 2016;75:1843-7.

35. Taylor PC, Weinblatt ME, Burmester GR, Rooney TP, Witt S, Walls CD, et al. Cardiovascular Safety During Treatment With Baricitinib in Rheumatoid Arthritis. Arthritis Rheumatol. 2019;71:1042-55.

36. Gossec L, Molto A, Romand X, Puyraimond-Zemmour D, Lavielle M, Beauvais C, et al. Recommendations for the assessment and optimization of adherence to disease-modifying drugs in chronic inflammatory rheumatic diseases: $\mathrm{A}$ process based on literature reviews and expert consensus. Joint Bone Spine. 2019;86:13-9.

37. Beauvais C, Pau D, Hautin-Monteil V, Ducrot MC, Veerabudun K, Flipo RM.

38. One-third of. patients are low-adherent to methotrexate for rheumatoid arthritis at the initiation of a first biologic. A cross-sectional study investigating adherence rate and factors. Joint Bone Spine. 2020;87:668-9.

39. Mary A, Boursier A, Desailly Henry I, Grados F, Séjourné A, Salomon S et al. Mobile Phone Text Messages and Effect on Treatment Adherence in Patients Taking Methotrexate for Rheumatoid Arthritis: A Randomized Pilot Study. Arthritis Care Res (Hoboken). 2019;71:1344-1352.

40. Svendsen MT, Andersen F, Andersen KH, Pottegård A, Johannessen H, Möller S, et al. Can an app supporting psoriasis patients improve adherence to topical treatment? A single-blind randomized controlled trial. BMC Dermatol. 2018;18:2.

41. Najm A, Lempp H, Gossec L, Berenbaum F, Nikiphorou E, et al. Needs, Experiences, and Views of People With Rheumatic and Musculoskeletal Diseases on Self-Management Mobile Health Apps: Mixed Methods Study. JMIR Mhealth Uhealth. 2020;20:e14351.

42. Knitza J, Simon D, Lambrecht A, Raab C, Tascilar K, Hagen M, et al. Mobile Health Usage, Preferences, Barriers, and eHealth Literacy in Rheumatology: Patient Survey Study. (JMIR Mhealth Uhealth. 2020;8(8):e19661. doi:10.2196/19661.

43. Grainger R, Townsley HR, Ferguson CA, Riley FE, Langlotz T, Taylor WJ. Patient and clinician views on an app for rheumatoid arthritis disease monitoring: function, implementation and implications. Int J Rheum Dis. 2020. https://doi.org/10.1111/1756-185X.13850.

44. Guillemin F, Saraux A, Guggenbuhl P, Roux C, Fardellone P, Le Bihan E, et al. Prevalence of rheumatoid arthritis in France: 2001. Ann Rheum Dis. 2005;64:1427-30.

45. Saraux A, Guillemin F, Guggenbuhl P, Roux C, Fardellone P. et al. Prevalence of spondyloarthropathies in France: 2001. Ann Rheum Dis. 2005;64:1431-5., Le Bihan E.

46. Magnol M, Berard ME, Rempenault EC, Castagne C, Pugibet B, Lukas M. Magnol M, Berard ME, Rempenault EC, Castagne C, Pugibet B, Lukas M. C et al. Use of ehealth by patients with rheumatoid arthritis: an observational, cross sectional, multicenter study. C et al. Ann Rheum Dis. 2020;79:532-3.

47. Stoyanov SR, Hides L, Kavanagh DJ, Zelenko O, Tjondronegoro D, Mani M. Mobile app rating scale: a new tool for assessing the quality of health mobile apps. JMIR Mhealth Uhealth 2015 Mar 11;3(1):e27.

48. Salazar A, de Sola H, Failde I, Moral-Munoz JA. Measuring the quality of mobile apps for the management of pain: systematic search and evaluation using the mobile app rating scale. JMIR Mhealth Uhealth. 2018;6(10):e10718.

\section{Figures}


Figure 1. The 4 non-linear stages of the patient's "career" of living with inflammatory arthritis

\begin{tabular}{|c|c|c|c|}
\hline $\begin{array}{c}\text { from } 1^{\text {st }} \text { symptoms to } \\
\text { diagnosis }\end{array}$ & $\begin{array}{l}\text { search for the right } \\
\text { treatment and right } \\
\text { dosage }\end{array}$ & $\begin{array}{c}\text { stabilization of } \\
\text { the disease and } \\
\text { treatment }\end{array}$ & $\begin{array}{l}\text { dealing with } \\
\text { complications or } \\
\text { unexpected events }\end{array}$ \\
\hline $\begin{array}{l}\text { - can be quick or } \\
\text { take years } \\
\text { - at stake: to find the } \\
\text { right doctor and } \\
\text { the right diagnosis } \\
\text { - patients search for } \\
\text { information }\end{array}$ & $\begin{array}{l}\text { - determined by the } \\
\text { patient's response } \\
\text { to treatment } \\
\text { - implies a close } \\
\text { joint effort } \\
\text { between patients } \\
\text { and doctor }\end{array}$ & $\begin{array}{l}\text { - patients develop } \\
\text { routines and habits } \\
\text { with their } \\
\text { treatment } \\
\text { - the treatment may } \\
\text { stop working }\end{array}$ & $\begin{array}{l}\text { - a complication or } \\
\text { an accident that } \\
\text { necessitates } \\
\text { emergency } \\
\text { measures }\end{array}$ \\
\hline $\begin{array}{l}\text { Sub-theme 1a: } \\
\text { information needs }\end{array}$ & $\begin{array}{l}\text { Sub-theme 1b: } \\
\text { partnership with } \\
\text { doctor }\end{array}$ & $\begin{array}{l}\text { Sub-theme } 1 \mathrm{c}: \\
\text { routines/habits }\end{array}$ & $\begin{array}{l}\text { Sub-theme 1d: } \\
\text { safety/side effects/ } \\
\text { complications }\end{array}$ \\
\hline
\end{tabular}

\section{Figure 1}

The 4 non-linear stages of the "patient's" career of living with inflammatory arthritis

Figure 2: Installations of the app from October 2017 to November 2020 at both stores

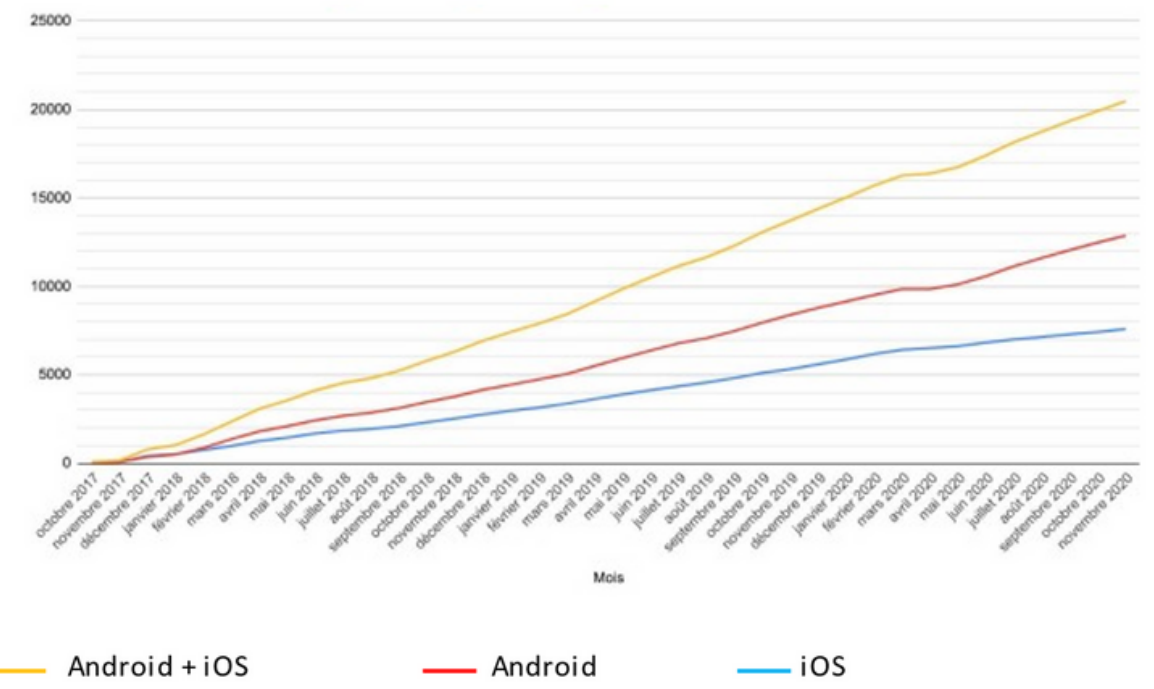

Figure 2 
Figure 3: Number of installations and mean number of regular users* since October 2017

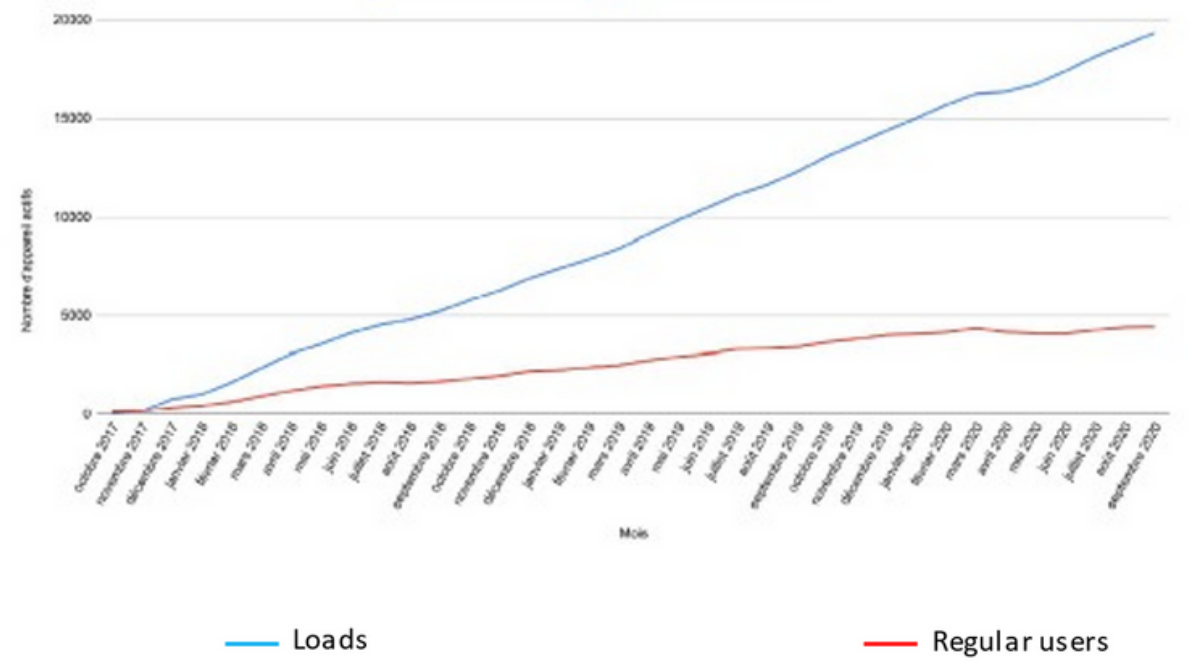

* Regular useindividualsing the app once a month or more (data from Android + iOS)

\section{Figure 3}

Number of installations and and mean number of regular users* since October 2017

\section{Supplementary Files}

This is a list of supplementary files associated with this preprint. Click to download.

- Supplementarymaterial1VF.docx

- Supplementarymaterial2VF.docx

- Supplementarymaterial3VF.docx

- Supplementarymaterial4VF.docx

- Supplementarymaterial5VF.docx

- Supplementarymaterial6VF.docx

- Supplementarymaterial7VF.docx

- Supplementarymaterial8VF.docx 